\title{
Spor Çalışanlarında Örgütsel Sessizlik ile Örgütsel Vatandaşlık Davranışı Arasındaki İlişkinin İncelenmesi
}

\author{
Examination of Relationship Between Organizational Silence and \\ Organizational Citizenship Behaviour in Sport Employees
}

Arif ÇETIN ${ }^{*}$

\begin{abstract}
Öz
Bu çalışma, İstanbul'da spor sektöründe çalışanların örgütsel sessizlik algısının örgütsel vatandaşlık davranışları üzerindeki etkilerini araştırmayı amaçlanmıştır. Spor sektöründe, bu iki değişken arasındaki ilişkiyi inceleyen çalışmalar sınırlıdır. Bundan dolayı bu çalışma, literatürdeki bu boşluğu doldurmaya çalışmıştır. Araştırmanın örneklemini, İstanbul Spor Sektöründe çalışan spor profesyonelleri arasından gönüllü seçim yöntemiyle seçilen 372 profesyonel çalışan oluşturmaktadır. Araştırmada veri toplama aracı olarak örgütsel sessizlik ölçeği Van Dyne ve diğ. (2003), örgütsel vatandaşlık ölçeği Podsakoff ve McKenzie (1989) tarafından geliştirilmiş ölçekler seçilmiştir. Örgütsel sessizliğin alt boyutları ile örgütsel vatandaşlık arasındaki ilişkiler faktör analizi, korelasyon analizi ve regresyon analizleri ile test edilmiştir. Araştırma sonucunda iki sonuç elde edilmiştir. Birincisi örgütsel sessizlik ile örgütsel vatandaşlık arasındaki ilişkinin var olduğudur $(\mathrm{p}<0.05)$. İkincisi, kabullenici ve korunma amaçlı sessizliğin örgütsel vatandaşlık davranışı üzerinde olumsuz etkisi olurken, koruma amaçlı sessizliği ise örgütsel vatandaşlık davranışı üzerinde olumlu etkisi vardır $(\mathrm{p}<0.05)$. Sonuç olarak hem özel hem de kamu spor kuruluşlarının üst yönetimi, olumsuz hususları önlemek ve olumlu davranışların oluşmasını teşvik etmek için zorunlu ve gerekli önlemler almalıdır.
\end{abstract}

Anahtar Kelimeler: Örgütsel sessizlik, örgütsel vatandaşlık davranışı, spor

\begin{abstract}
The study aimed to investigate the effects of organizational silence perception on organizational citizenship behaviours of employees in the sports sector in Istanbul. There is an inadequate amount of studies examining the relationship both two variables, uniquely in the sports sector. Hence, this study tried to fill this gap in the literature. The sample of this study consisted of 372 professional employees chosen by the voluntary selection method among sports professionals who are working in Istanbul Sports Sector. In the research, the organizational silence scale is developed by Van Dyne et al. (2003) and organizational citizenship scale is developed by Podsakoff and McKenzie (1989) were chosen as a data collection tool. The relations between sub-dimensions of organizational silence and organizational citizenship were tested with factor analysis, correlation analysis and regression analyses. Two outcomes were obtained as a result of
\end{abstract}

* Dr. İBB Spor İstanbul, arifcetin1985@yahoo.com 
the research. The first was that there was a relationship between organizational silence and organizational citizenship $(\mathrm{p}<0.05)$. The second was that acquiescent silence and defensive silence were effected on organizational citizenship behaviour negatively, while prosocial silence effects on positively $(\mathrm{p}<0.05)$. In conclusion, the senior administration of sports organizations, both private and public, should take urgent and required actions to prevent negative issues and encourage positive behaviour from occurring.

Keywords: Organizational silence, organizational citizenship behaviour, sport

\section{INTRODUCTION}

In recent years, organizations have started to do some work in order to improve their real potential with the effect of increasing competition and to communicate about their occurrence in competitive market situations. Organizations with the importance of human powers are employees to have attempted to develop internal policies in order to increase their satisfaction (Çetin, 2019).

Organizational citizenship behaviour is defined as voluntary effort, a common belief and high role behaviours that organization employees show differently from their working environments and job descriptions (Yücel and Samanc1, 2009). Besides, organizational citizenship behaviour is defined as an employee voluntarily going beyond the organization's job descriptions and doing more than desired (Greenberg and Baron, 2000). In this context, employees working in organizations where organizational citizenship is internalized consider the interests of the organization high level. It avoids behaviour that will harm the organization and enables good relations between management and employees.

Organizational citizenship behaviour has been becoming increasingly essential for organizations over the decade. It is defined as individual behaviours that are not explained precisely in the organization's formal bonus policy and contribute to the effective functioning of the organization. These behaviours are voluntarily performed by employees and do not require any responsibility if not done. Organizational citizenship behaviour, which means beyond the formal requirements of the job, has also taken different names in different studies such as over-role behaviours and social organization behaviours beyond formal job descriptions. However, it is not correct to consider organizational citizenship behaviour as the one-to-one excess role in any case. Employees who demonstrate excessive role behaviour are aware of the level of their behaviour and expected to be formally rewarded for these behaviours (Ones, et al. 2018).

Besides, organizational silence strengthens effective decision-making mechanisms in an organization and, also provides flexibility and durability for the organization to adapt to the changing environment. Organizational silence also contributes to identifying problems within the organization and to the development of the organization. Furthermore, preventing organizational silence in an organization plays a vital role in employees 'positive work behaviour and mood, and employees' acting as a citizen of the organization (Morrison and Milliken, 2000). In the sports sector, studies covering these two variables are almost non-existent in the literature. Examining in the literature whether organizational silence has a different effect on organizational citizenship behaviour compared to previous studies advances this study different from previous studies (He, et al., 2017; Fatima, 2015; Kılıçlar and Harbalioglu, 2014). 


\section{Organizational Silence}

Organizational silence is a phenomenon that has recently started to be the subject of organizational behaviour research. This behaviour is frequently experienced in organizations. It is exhibited in the form of not expressing thoughts, ideas, concerns and suggestions about the workplaces of the employees, their jobs or other activities of the organization (Morrison and Milliken, 2000). If this situation takes the form of a group decision, it is discussed at the organizational level. While many researchers viewed the behaviour of silence from individual perspectives, many claimed that there was a group behaviour at the organizational level. It can take the form of a climate as it is considered as behaviour that employees exhibit collectively (Henriksen and Dayton, 2006). However, silence has also been defined as an individual-level behaviour. It is the hiding and sharing of behavioural, cognitive and emotional real and sincere expressions about the development of organizational conditions of people who can change and improve any situation. Silence can be perceived as a passive behaviour conceptually. It can also occur in silence, deliberate, active and consciously (Pinder and Harlos, 2001).

In the literature, there can be mentioned two necessary conceptual studies directly related to silence in organizations. The first of these studies explain the process of silence, the causes and the organizational conditions that have been carried out by Morrison and Milliken (2000). The second was done by Pinder and Harlos (2001), and they focused on the influence of researchers on the decision of the employees to decide whether to speak explicitly or not.

The concept of organizational silence can be seen in different ways within the organization. Van Dyne et al. (2003) stated that employees could show three varieties of silence behaviour, including acquiescence, defensive and prosocial.

Acquiescence silence defined as the self-preservation of employees' opinions, knowledge and feelings that will improve their businesses and organizations, and the individual's knowledge, advice, or statement about the situation or event. Employees did not prefer not to express their opinions voluntarily. Therefore, employees prefer to remain silent with the idea that speaking is a futile attempt (Van Dyne, et al. 2003). There are information and behaviour of the individual to avoid communicating is observed for this reason.

As defensive silence, the employee prefers to remain silent with the motive of self-defence behaviour based on anxiety and fear (Riantoputra, et al. 2016). The employee can act as if there are no existing problems, hide personal mistakes or choose not to convey different opinions and ideas to protect itself.

Van Dyne et al. (2003) defined prosocial silence as employees' negligence to say their opinions, information and judgments about their profession and organization, to benefit from the organization or other individuals for reasons of considering about others or collaborative goals.

Many studies on organizational silence have been conducted in sports literature. These studies were general studies that deal with organizational performance on gender (Baştuğ, et al. 2016) and working performance and silence (Algün Doğu and Yılmaz, 2017). 
The concept causes anxiety, cynicism, displeasure and disruption among colleagues (Tamuz, 2001). Besides, organizational silence leads to a sense of lack of value in employees, perception of lack of control, low effort to achieve organizational goals, and cognitive dissonance (Morrison, 2014). The main issues arising from organizational silence are the inability of employees to produce new thoughts and to be open-minded. Employees must contribute to the organization by generating unique views so that organizations can develop and sustain it. There are not many problems arising from the silence. Because the encouragement of the employees in some organizations respects the ideas from employees, organizations that encourage their employees and listen to their problems are expected to be more successful than other organizations (Özdemir and Uğur, 2013).

\section{Organizational Citizenship}

The foundation of organizational citizenship behaviour is based on social exchange theory. Based on the opinion that the employee organizational relationship goes exceeding a simple economic clearance agreement, employees make more extra efforts than they require in the hope that they will be rewarded in the future. Organizational citizenship behaviour, which is an explanation of the extra efforts exhibited, is expressed as behaviours that benefit the organization without waiting for a response beyond the formal role obligations. Within the framework of social exchange theory, members of the organization are anticipated to behave beyond their job descriptions (Elstad, et al. 2011).

Organ (1988) stated that employees could show five different types of organizational citizenship, including altruism, conscientiousness, courtesy, civic virtue and sportsmanship.

Altruism is sacrificing in some situations that do not fall within the boundaries of tasks and assisting colleagues while others do their jobs such as without problem of performing unforeseen jobs in the organization (Organ, 1988).

The concept of conscientiousness is expressed by the high duty awareness of the employees. It is revealed with the devoted efforts of employees who cannot finish his job, leaving the office before their job are finished, adapting to break times, not disrupting their career even when they are sick (Organ, 1988).

Behaviours such as informing individuals about the decisions taken and informing about developments are classified in courtesy dimension to prevent problems (Wan, 2018).

Civic virtue refers to the commitment to organization whole dimensions and to show citizenship behaviour for the benefit of the organization at the holistic level. Organizational members express their thoughts in the business and show voluntary acts such as participating in decisions. Behaviours such as the active and voluntary participation of employees in the policy and decision-making processes, their continuous involvement in meetings, and the active role in supporting and supporting social activities are examples of civic virtue (Yeşilyurt and Koçak, 2014).

The concept of sportsmanship is the behaviours that the employees exhibit to avoid showing adverse reactions that may cause conflicts and quarrels with their colleagues in the organization. An example 
of this behaviour is that employees do not enlarge problems, take time to offer solution alternatives rather than expressing issues, and manage this process with understanding (Bağc1, 2014).

Numerous examinations have been carried in the literature on organizational citizenship behaviour in sport. These studies exoterically addressed attitude and view of organizational citizenship from athletes (Love and Kim, 2018), the impact of organizational citizenship behaviour on performance (Basu, et al. 2015), relationships with leadership, team cohesion, and job satisfaction (Aoyagi, et al. 2008).

\section{Organizational Citizenship and Organizational Silence Relationship}

There are many studies in the literature examining the correlation between organizational citizenship behaviour and organizational silence. Some of these studies are as follows:

The relationship between organizational citizenship and organizational silence has been examined within the framework of healthcare professionals. In the study, it was determined that there is a relationship between both variables (Kılınç and Ulusoy, 2014).

In another study, the relationship between organizational silence and organizational citizenship behaviour was studied in the connection of employees in the private sector. In the results of the research, acquisition silence and defensive silence were negative, while organizational prosocial silence was found to have a positive effect on organizational citizenship behaviour (Çınar, et al. 2013).

In another study, the sub-dimensions of organizational citizenship and organizational silence were addressed. In this study, it was ascertained that civic virtue and sportsmanship sub-dimensions had a negative and significant relationship on organizational silence. In other sub-dimensions of organizational citizenship, a meaningful relationship could not be classified (Acaray and Akturan, 2015).

It is found in the literature that there are an inadequate number of studies in sports organizations where these two concepts are implemented in many businesses.

\section{METHODS}

The research is a descriptive research in relational screening model. Organizational citizenship behaviour stays at the centre of the research model. In the study, it will be examined whether there is any relationship between organizational citizenship and organizational silence. In the same direction, the impact of organizational silence on organizational citizenship also be explored. 


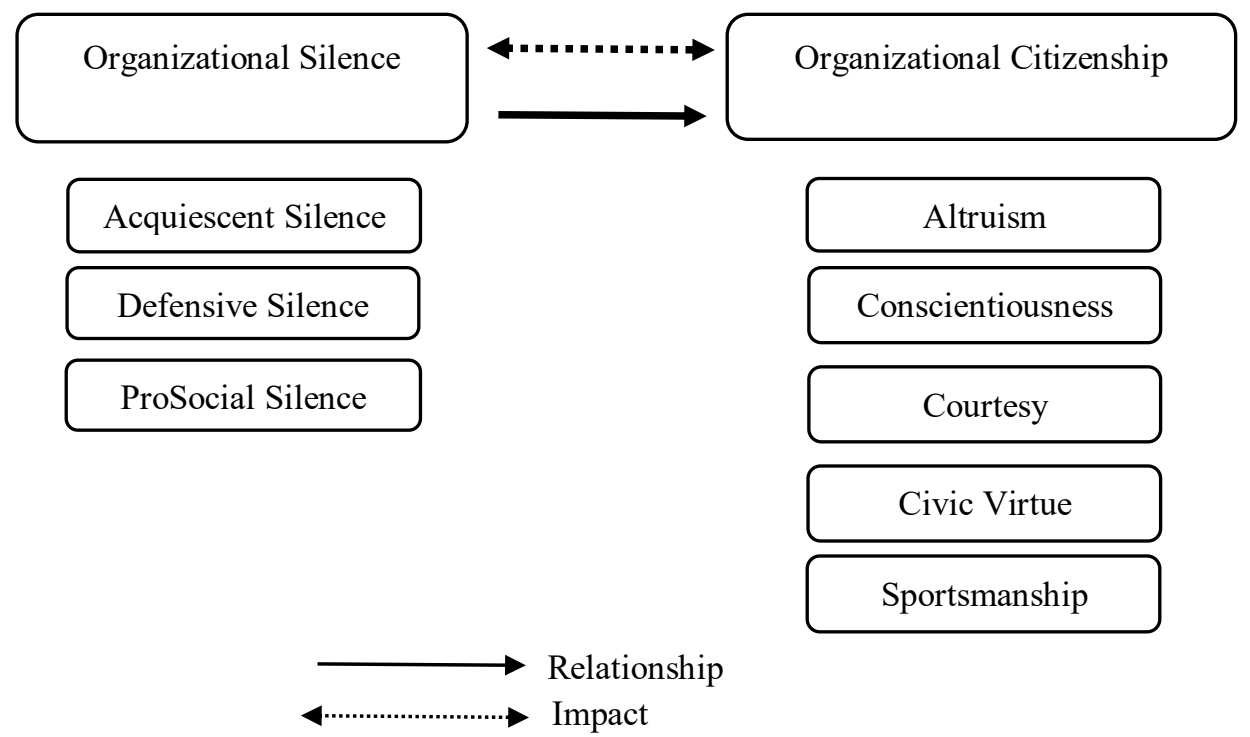

Figure1. Research Model

\section{Participants}

The sample of this study consisted of 372 employees selected by the convenient and accessible sampling method among sports professionals who are working in Spor Istanbul. 58.9\% $(\mathrm{n}=219)$ of the participants were male, $41.1 \%(n=153)$ were female, and 79,3\% $(n=295)$ of the participants were married. The largest age group was 35-44 years with $46,2 \%(n=172) ; 64.2 \%(n=239)$ of the participants are university graduated. Among the participants, $36,8 \%(n=137)$ the group of 5000 TRY and over were the most dominant group in terms of monthly income.

\section{Procedure}

After official approval from the organization, sports professionals were informed about the objectives and use of the information-professionals who voluntarily participated in an online questionnaire.

The survey is consisting of 40 items and demographic variables to sports professionals who are working in Spor Istanbul. Descriptive survey method is preferred to analyse the perceptions of organizational silence and organization citizenship of sports professionals. A total of 372 responses were preserved for analysis.

\section{Measurement}

The research was quantitative research and questionnaire was chosen as the data collection tool. 5-point Likert-type scale was used in the survey that is consists of two parts. In the first part of the questionnaire, there are demographic questions about the participants' gender, age, marital 
status, education and income status. In the second part; there are 15 statements to determine the perception of organizational silence of workers, while there are 20 statements to determine the levels of organizational citizenship behaviour. In the study, the scale developed by Van Dyne, et al. in 2003, translated into Turkish by Taşkıran (2010) for "Organization Silence" was used.

Podsakoff and McKenzie developed the "Organizational Citizenship Behaviour Scale" (1989), translated into Turkish by Mehtap (2011) and consists of 20 statements. Organizational citizenship behaviour scale consists of five dimensions with 15 expressions. Reflective scales were used for all variables (Kleijnen, et al. 2007).

\section{Data Analysis}

SPSS 25.0 package program was used in the analysis of the data collected from the research. The suitability of the data to normal distribution was examined, and it was analysed that all data groups were normally distributed. Descriptive statistical methods, correlation analysis and multiple regression analysis were used in the analysis of the data obtained from the study.

\section{RESULTS}

Table 1. Demographic Valuables

\begin{tabular}{lll}
\hline Gender & Frequency & Percent \\
\hline Male & 219 & 58,9 \\
Female & 153 & 41,1 \\
Total & 372 & 100,0 \\
\hline Marital Status & Frequency & Percent \\
\hline Married & 77 & 20,7 \\
Single & 295 & 79,3 \\
Total & 372 & 100,0 \\
\hline Age & Frequency & Percent \\
\hline 18-24 & 17 & 4,6 \\
$25-34$ & 164 & 44,1 \\
$35-44$ & 172 & 46,2 \\
$45-54$ & 19 & 5,1 \\
Total & 372 & 100,0 \\
\hline Educational Status & Frequency & Percent \\
\hline Associate Degree & 87 & 23,4 \\
University & 239 & 64,2 \\
Postgraduate & 46 & 12,4 \\
Total & 372 & 100,0 \\
\hline Monthly Income (TL) & Frequency & Percent \\
\hline 2751-3500 & 16 & 4,3 \\
3501-4250 & 104 & 28,0 \\
$4251-5000$ & 115 & 30,9 \\
5000 and above & 137 & 36,8 \\
Total & 343 & 100,0 \\
\hline
\end{tabular}


As can be seen in Table 1, 58.9\% ( $\mathrm{n}=219)$ of the participants were male, $41.1 \%(\mathrm{n}=153)$ were female, and $79,3 \%(n=295)$ of the participants were married. The largest age group was 35-44 years with $46,2 \%(\mathrm{n}=172) ; 64.2 \%(\mathrm{n}=239)$ of the participants are university graduated. Among the participants, $36,8 \%(n=137)$ the group of 5000 TRY and over were the most dominant group in terms of monthly income.

Table 2. Factor loads for endogenous variables

\begin{tabular}{|c|c|c|c|c|c|c|c|c|}
\hline & Acquiescent & Defensive & Prosocial & Altruism & Courtesy & $\begin{array}{l}\text { Civic } \\
\text { Virtue }\end{array}$ & Sportsmanship & Conscientious \\
\hline Acquiescent1 &, 862 & & & & & & & \\
\hline Acquiescent2 & 815 & & & & & & & \\
\hline Acquiescent3 & ,784 & & & & & & & \\
\hline Acquiescent4 & ,705 & & & & & & & \\
\hline Acquiescent5 & 899 & & & & & & & \\
\hline Defensive1 & & 975 & & & & & & \\
\hline Defensive2 & & ,951 & & & & & & \\
\hline Defensive3 & & ,824 & & & & & & \\
\hline Defensive4 & & 957 & & & & & & \\
\hline Defensive5 & & 975 & & & & & & \\
\hline ProSociall & & & ,868 & & & & & \\
\hline ProSocial2 & & & 942 & & & & & \\
\hline ProSocial3 & & &, 737 & & & & & \\
\hline ProSocial4 & & & ,932 & & & & & \\
\hline ProSocial5 & & & ,930 & & & & & \\
\hline Alturism1 & & & & 881 & & & & \\
\hline Alturism2 & & & & ,912 & & & & \\
\hline Alturism3 & & & & ,804 & & & & \\
\hline Alturism4 & & & & ,938 & & & & \\
\hline Courtesyl & & & & & ,923 & & & \\
\hline Courtesy2 & & & & & ,909 & & & \\
\hline Courtesy3 & & & & & 847 & & & \\
\hline Courtesy4 & & & & & ,938 & & & \\
\hline CivicVirtue1 & & & & & &, 857 & & \\
\hline CivicVirtue2 & & & & & & 942 & & \\
\hline CivicVirtue3 & & & & & & ,913 & & \\
\hline CivicVirtue4 & & & & & & ,955 & & \\
\hline Sportmanship1 & & & & & & & 982 & \\
\hline Sportmanship2 & & & & & & & ,852 & \\
\hline Sportmanship3 & & & & & & & ,778 & \\
\hline Sportmanship4 & & & & & & & 953 & \\
\hline Conscientiousness1 & & & & & & & & 948 \\
\hline Conscientiousness2 & & & & & & & & 870 \\
\hline Conscientiousness 3 & & & & & & & & ,777 \\
\hline Conscientiousness 4 & & & & & & & & ,905 \\
\hline
\end{tabular}


The standardized loading of the measurements on the relevant concepts was calculated by confirmatory factor analysis (CFA) and it was found that all measurements tested in convergent validity showed that a standardized loading exceeding 0,60 to their factors.

Table 3. Reliability and validity values

\begin{tabular}{lccccc}
\hline Variables & Mean & Variance & Std. Deviation & Cronbach's Alpha & N of Items \\
\hline Acquiescent & 8,86 & 10,325 & 3,213 &, 868 & 5 \\
Defensive & 7,85 & 8,604 & 2,933 &, 938 & 5 \\
ProSocial & 19,62 & 15,078 & 3,883 &, 852 & 5 \\
Altruism & 16,20 & 5,114 & 2,261 &, 817 & 4 \\
Courtesy & 17,64 & 5,088 & 2,256 &, 900 & 4 \\
Sportsmanship & 17,05 & 7,218 & 2,687 &, 896 & 4 \\
Conscientiousness & 17,33 & 3,714 & 1,927 &, 878 & 4 \\
Civic Virtue & 7,62 & 9,887 & 3,144 &, 874 & 4 \\
Total & & & & & 35 \\
\hline
\end{tabular}

The average and standard deviation values calculated according to the dimensions of the scales used in the study are shown in Table 3. The scale is highly reliable in the range of $0.80 \leq \alpha<1.00$. In line with this data, a reliability test was performed to determine the reliability value of the scales. The Cronbach Alpha reliability value of the scale is 0.868 ; defensive 0.938 ; prosocial 0.852 ; altruism 0.817 ; courtesy 0,900 ; sportsmanship 0.896 ; conscientiousness 0.878 ; civic virtue has been determined to be 0.874 . These values indicate that the scale is highly reliable (Kayış, 2009).

Table 4. Correlations values

\begin{tabular}{lcccccccc}
\hline & 1 & 2 & 3 & 4 & 5 & 6 & 7 & 8 \\
\hline Acquiescent (1) & $\mathbf{1}$ &, $753^{* *}$ &,$- 411^{* *}$ &,$- 462^{* *}$ &,$- 585^{* *}$ &, $591^{* *}$ &,$- 434^{* *}$ &,$- 640^{* *}$ \\
Defensive (2) &, $753^{* *}$ & $\mathbf{1}$ &,$- 397^{* *}$ &,$- 408^{* *}$ &,$- 632^{* *}$ &, $540^{* *}$ &,$- 579^{* *}$ &,$- 741^{* *}$ \\
ProSocial (3) &,$- 411^{* *}$ &,$- 397^{* *}$ & $\mathbf{1}$ &, $293^{* *}$ &, $345^{* *}$ &,$- 231^{* *}$ &, $313^{* *}$ &, $492^{* *}$ \\
Altruism (4) &,$- 462^{* *}$ &,$- 408^{* *}$ &, $293^{* *}$ & $\mathbf{1}$ &, $741^{* *}$ &,$- 269^{* *}$ &, $489^{* *}$ &, $776^{* *}$ \\
Courtesy (5) &,$- 585^{* *}$ &,$- 632^{* *}$ &, $345^{* *}$ &, $741^{* *}$ & $\mathbf{1}$ &,$- 597^{* *}$ &, $752^{* *}$ &, $882^{* *}$ \\
Civic Virtue (6) &, $591^{* *}$ &, $540^{* *}$ &,$- 231^{* *}$ &,$- 269^{* *}$ &,$- 597^{* *}$ & $\mathbf{1}$ &,$- 415^{* *}$ &,$- 529^{* *}$ \\
Sportsmanship (7) &,$- 434^{* *}$ &,$- 579^{* *}$ &, $313^{* *}$ &, $489^{* *}$ &, $752^{* *}$ &,$- 415^{* *}$ & $\mathbf{1}$ &, $791^{* *}$ \\
Conscientiousness (8) &,$- 640^{* *}$ &,$- 741^{* *}$ &, $492^{* *}$ &, $776^{* *}$ &, $882^{* *}$ &,$- 529^{* *}$ &, $791^{* *}$ & $\mathbf{1}$ \\
\hline
\end{tabular}

**. Correlation is significant at the 0.01 level (2-tailed).

Whether there is a statistically significant relationship between the dimensions examined in the study was tested by using Pearson Correlation analysis. It is showed that there are statistically significant relationships when the correlation coefficients between the organizational citizenship sub-dimensions and the organizational silence sub-dimensions are analysed. There was a negative statistically significant relationship between acquiescent and altruism $(r=0,462)$, courtesy $(r=0,585)$, sportsmanship ( $r=0,434)$ and conscientiousness $(r=0,640)$, a positive correlation was found between 
acquiescent dimension and civic virtue $(\mathrm{r}=0,591)$. As regards defensive silence, it was negative statistically significant relationship between defensive silence dimension and altruism $(r=0,408)$, courtesy $(r=0,632)$, sportsmanship $(r=0,579)$ and conscientiousness $(r=0,741)$, a positive correlation was found between defensive dimension and civic virtue $(\mathrm{r}=0,540)$. As regards prosocial silence, it was positive statistically significant relationship between prosocial silence dimension and altruism $(r=0,293)$, courtesy $(r=0,345)$, sportsmanship $(r=0,313)$ and conscientiousness $(r=0,492)$, a negative correlation was found between prosocial dimension and civic virtue $(r=0,540)$.

Multiple regression analysis was applied to determine the effect of this relationship on organizational citizenship behaviour sub-dimensions; after finding a statistically significant relationship between organizational silence and organizational citizenship sub-dimensions in the correlation analysis. In the analysis, organizational silence was employed as an independent, and organizational citizenship was employed as a dependent variable.

Table 5. Regression analysis results to determine effects of organizational silence on altruism

\begin{tabular}{|c|c|c|c|c|c|}
\hline & $\mathbf{R}$ & $\mathbf{R}^{2}$ & Adjusted $R^{2}$ & Std. Error of the Estimate & Sig \\
\hline \multicolumn{6}{|c|}{ Altruism } \\
\hline \multirow{2}{*}{ Acquiescent } & ,462 & ,0213 &, 211 &, 50217 & ,001 \\
\hline & & & Altruism & & \\
\hline \multirow[t]{2}{*}{ Defensive } & 408 &, 167 &, 164 &, 51679 &, 001 \\
\hline & & & Altruism & & \\
\hline Prosocial & ,293 &, 086 & 083 &, 54128 & ,001 \\
\hline
\end{tabular}

* There is a significant difference at $\mathrm{p}<0.05$ level.

The regression analysis findings made to explain the effect of the organizational silence subdimensions on the altruism sub-dimension are shown in Table 5. According to the results of the analysis, it was found that it has an effect on acquiescent $(p=0,000)$, defensive $(p=0,000)$ and prosocial $(\mathrm{p}=0,000)$ on the altruism. According to the model, the predictive effect of acquiescent to explain the altruism is $2.1 \%\left(\mathrm{R}^{2}, 0213\right)$; the effect of defensive on explaining altruism is $17 \%\left(\mathrm{R}^{2}, 167\right)$ and the effect of prosocial on explaining altruism is $8.6 \%\left(\mathrm{R}^{2}, 086\right)$. This result shows that the subdimensions of organizational silence have a positive effect on altruism.

Table 6. Regression analysis results to determine effects of organizational silence on courtesy

\begin{tabular}{|c|c|c|c|c|c|}
\hline & $\mathbf{R}$ & $\mathbf{R}^{2}$ & Adjusted $\mathrm{R}^{2}$ & Std. Error of the Estimate & Sig \\
\hline \multicolumn{6}{|c|}{ Courtesy } \\
\hline Acquiescent &, 513 &, 037 &, 585 & ,13869 &, 001 \\
\hline \multicolumn{6}{|c|}{ Courtesy } \\
\hline Defensive & ,632 & ,399 & ,398 &, 43760 &, 001 \\
\hline \multicolumn{6}{|c|}{ Courtesy } \\
\hline Prosocial & ,345 & ,119 & ,116 &, 53010 & ,001 \\
\hline
\end{tabular}

* There is a significant difference at $\mathrm{p}<0.05$ level. 
The regression analysis findings made to explain the effect of the organizational silence subdimensions on the courtesy sub-dimension are shown in Table 6. According to the results of the analysis, it was found that it has an effect on acquiescent $(\mathrm{p}=0,000)$, defensive $(\mathrm{p}=0,000)$ and prosocial $(\mathrm{p}=0,000)$ on the courtesy. According to the model, the predictive effect of acquiescent to explain the courtesy is $3,7 \%\left(R^{2}, 037\right)$; the effect of defensive on explaining courtesy is $40 \%\left(R^{2}, 399\right)$ and the effect of prosocial on explaining altruism is $12 \%\left(\mathrm{R}^{2}, 119\right)$. This result shows that the sub-dimensions of organizational silence have a positive effect on courtesy.

Table 7. Regression analysis results to determine effects of organizational silence on civic virtue

\begin{tabular}{|c|c|c|c|c|c|}
\hline & $\mathbf{R}$ & $\mathbf{R}^{2}$ & Adjusted $\mathrm{R}^{2}$ & $\begin{array}{l}\text { Std. Error of the } \\
\text { Estimate }\end{array}$ & Sig \\
\hline \multicolumn{6}{|c|}{ Civic Virtue } \\
\hline Acquiescent & ,591 & ,0349 & ,347 & 63502 & ,001 \\
\hline \multicolumn{6}{|c|}{ Civic Virtue } \\
\hline Defensive & ,540 & 291 & ,289 & ,66262 & ,001 \\
\hline \multicolumn{6}{|c|}{ Civic Virtue } \\
\hline Prosocial & ,231 &, 053 & 051 & ,76589 & ,001 \\
\hline
\end{tabular}

* There is a significant difference at $\mathrm{p}<0.05$ level.

The regression analysis findings made to explain the effect of the organizational silence subdimensions on the civic virtue sub-dimension are shown in Table 7. According to the results of the analysis, it was found that it has an effect on acquiescent $(p=0,000)$, defensive $(p=0,000)$ and prosocial $(\mathrm{p}=0,000)$ on the civic virtue. According to the model, the predictive effect of acquiescent to explain the civic virtue is $3,49 \%\left(\mathrm{R}^{2}, 0349\right)$; the effect of defensive on explaining altruism is $29 \%$ $\left(\mathrm{R}^{2}, 291\right)$ and the effect of prosocial on explaining altruism is $5.3 \%\left(\mathrm{R}^{2}, 053\right)$. This result shows that the sub-dimensions of organizational silence have a positive effect on civic virtue.

Table 8. Regression analysis results to determine effects of organizational silence on sportsmanship

\begin{tabular}{|c|c|c|c|c|c|}
\hline & $\mathbf{R}$ & $\mathbf{R}^{2}$ & Adjusted $\mathrm{R}^{2}$ & Std. Error of the Estimate & Sig \\
\hline \multicolumn{6}{|c|}{ Sportsmanship } \\
\hline \multirow[t]{2}{*}{ Acquiescent } & ,434 & ,189 & ,187 & ,60581 & ,001 \\
\hline & & & Sportsmans & & \\
\hline \multirow[t]{2}{*}{ Defensive } & 579 &, 336 & ,334 &, 54819 &, 001 \\
\hline & & & Sportsmans & & \\
\hline Prosocial & ,313 & ,0898 &, 095 & ,63880 & 001 \\
\hline
\end{tabular}

* There is a significant difference at $\mathrm{p}<0.05$ level.

The regression analysis findings made to explain the effect of the organizational silence subdimensions on the sportsmanship sub-dimension are shown in Table 8. According to the results of the analysis, it was found that it has an effect on acquiescent $(p=0,000)$, defensive $(p=0,000)$ and prosocial ( $\mathrm{p}=0,000)$ on the sportsmanship. According to the model, the predictive effect of acquiescent 
to explain the sportsmanship is $19 \%\left(\mathrm{R}^{2}, 0189\right)$; the effect of defensive on explaining sportsmanship is $34 \%\left(\mathrm{R}^{2}, 336\right)$ and the effect of prosocial on explaining altruism is $9 \%\left(\mathrm{R}^{2}, 089\right)$. This result shows that the sub-dimensions of organizational silence have a positive effect on sportsmanship.

Table 9. Regression analysis results to determine effects of organizational silence on conscientiousness

\begin{tabular}{lccccc}
\hline & $\mathbf{R}$ & $\mathbf{R}^{2}$ & Adjusted $\mathbf{R}^{2}$ & Std. Error of the Estimate & Sig \\
\hline Acquiescent & \multicolumn{5}{c}{ Conscientiousness } \\
\hline &, 640 &, 409 &, 408 &, 37080 &, $\mathbf{0 0 1}$ \\
\hline Defensive &, 741 &, 548 & Conscientiousness &, 32419 &, $\mathbf{0 0 1}$ \\
\hline \multicolumn{7}{c}{ Conscientiousness } \\
\hline Prosocial &, 492 &, 242 &, 240 &, 42007 &, $\mathbf{0 0 1}$ \\
\hline
\end{tabular}

* There is a significant difference at $\mathrm{p}<0.05$ level.

The regression analysis findings made to explain the effect of the organizational silence subdimensions on the conscientiousness sub-dimension are shown in Table 9. According to the results of the analysis, it was found that it has an effect on acquiescent $(p=0,000)$, defensive $(p=0,000)$ and prosocial $(\mathrm{p}=0,000)$ on the conscientiousness. According to the model, the predictive effect of acquiescent to explain the conscientiousness is $41 \%\left(\mathrm{R}^{2}, 409\right)$; the effect of defensive on explaining conscientiousness is $55 \%\left(\mathrm{R}^{2}, 548\right)$ and the effect of prosocial on explaining conscientiousness is $24 \%$ $\left(\mathrm{R}^{2}, 242\right)$. This result shows that the sub-dimensions of organizational silence have a positive effect on conscientiousness.

\section{DISCUSSION}

The aim of the study was whether there was any relationship between organizational citizenship and organizational silence. In the same direction, the impact of organizational silence was investigated on organizational citizenship behaviour.

The first finding of the study is the relationship between organizational silence subscales and organizational citizenship sub-dimensions. According to this result, it can be said that the results of the research between organizational silence and organizational citizenship of the employees in the sports sector are consistent with other studies (Nafei, 2016; Acaray and Akturan, 2015; Kilınç, 2012).

Studies that examine these two variables both as one dimension and their sub-dimensions are as follows:

There was found a positive relationship between prosocial silence and organizational citizenship behavior in the study which covers 1323 employees in various industrial organizations (Şehitoğlu, 2010). Furthermore, similar results were found in the study conducted by Kılınç (2012) for 317 healthcare professionals and also in the study of Acaray and Akbolat (2015) with 462 employees in various sectors. Additionally, prosocial silence found a positive effect on authoritative citizenship 
behaviour in a study by Raju and Tamjis (2019). Hence, the single sub-dimension of organizational silence was compared with organizational citizenship behaviour, and the findings coincide with the results of this study.

There was also found a negative relationship between organizational silence and organizational citizenship behavior in the study which covers 392 employees in hotel sector (Kılıçlar and Harbalıoğlu, 2014). Moreover, similar results were found in the study conducted by Khan et al. (2016) for 220 managers in the education institution and also in the study of Bulunuz (2019) with 469 nurses in health sector. These variables are considered as a single dimension in these studies, and the findings do not match in the study.

Therefore, the results of the researches are generally that there is a negative relationship between organizational citizenship and organizational silence in the literature. Besides, there was a significant negative relationship with an acquiescent, defensive, and positive relationship with prosocial silence, when organizational silence and organizational citizenship behaviour are analysed in the context of sub-dimensions level as in this research.

Altruism and organizational silence sub-dimensions were examined. It was determined that there was a significant negative relationship with acquiescent, defensive and positive relationship with prosocial silence. It was also found that sports professionals have displayed acts of acquiescent the most on the altruism.

Courtesy and organizational silence sub-dimensions were considered. It was determined that there was a significant negative relationship with acquiescent, defensive and positive relationship with prosocial silence. It was also found that sports professionals have displayed acts of acquiescent the most on the courtesy.

Civic Virtue and organizational silence sub-dimensions were observed. It was determined that there was a significant negative relationship with acquiescent, defensive and positive relationship with prosocial silence. It was also found that sports professionals have displayed acts of acquiescent the most on civic virtue.

Sportsmanship and organizational silence sub-dimensions were analysed. It was determined that there was a significant negative relationship with acquiescent, defensive and positive relationship with prosocial silence. It was also found that sports professionals have displayed acts of defensive the most on the sportsmanship.

Conscientiousness and organizational silence sub-dimensions were examined. It was determined that there was a significant negative relationship with acquiescent, defensive and positive relationship with prosocial silence. It was also found that sports professionals have displayed acts of defensive the most on the conscientiousness.

Two outcomes were obtained as a result of the research. The first is the relationship between organizational silence and organizational citizenship. The second is that sub-dimensions acquiescent 
and defensive effect on organizational citizenship behaviour negatively, while prosocial effects on positively. Therefore, senior management of sports organizations both private and public should take necessary actions to prevent negative issues and promote positive behaviour from occurring. These actions can be listed as follows.

Providing a positive dialogue atmosphere between employees

Incorporation of all employees in decision mechanisms

Employees should be allowed to express their thoughts on their duties.

Senior management should create an environment where staff can express their opinions and suggestions easily.

\section{REFERENCES}

Acaray, A. \& Akturan, A. (2015). The Relationship between Organizational Citizenship Behaviour and Organizational Silence. Procedia - Social and Behavioral Sciences, 207. 472-482.

Algün Doğu, G. \& Yılmaz, B . (2017). Gençlik ve Spor Bakanlığı Merkez Teşkilatı Çalışanlarının Örgütsel Adalet ile Örgütsel Sessizlik Algıları Arasındaki İlişki Üzerine Bir Araştırma. CBÜ Beden Eğitimi ve Spor Bilimleri Dergisi , 12 (1) , 16-27

Aoyagi, M., Cox, R. \& McGuire, R. (2008). Organizational Citizenship Behavior in Sport: Relationships with Leadership, Team Cohesion, and Athlete Satisfaction. Journal of Applied Sport Psychology, 20. 25-41.

Bağcı, Z. (2014). Duygusal Zeka ve Örgütsel Vatandaşlık İlişsisi, Hitit Üniversitesi Sosyal Bilimler Enstitüsü Dergisi, 2, 259-279.

Baştuğ, G., Pala, A. \& Yilmaz, T., Duyan, M. \& Günel, I. (2016). Organizational Silence in Sports Employees. Journal of Education and Learning, 5, 126.

Basu, E., Pradhan, R. \& Jena, L. (2015). Organizational Citizenship Behaviour, Job Performance and HR Practices: A Relational Perspective. Management and Labor Studies. 39. 1-12.

Bulunuz, A. (2019). Örgütsel Vatandaşlik ve Örgütsel Sessizlik Arasindaki İlişki: Bir Alan Araştırması. Yüksek Lisans Tezi, Kırklareli Üniversitesi Sosyal Bilimler Enstitüsü Sağlik Kuruluşlari Yöneticiliği Anabilim Dalı.

Çetin, A. (2019). Sporda Örgütsel Adalet, Örgütsel Güven ve Örgütsel Bağlllık İlişkisi. Ankara: Spor Yayınevi.

Çınar, O., Karcıoğlu, F., \& Alioğulları, Z. D. (2013). The Relationship between Organizational Silence and Organizational Citizenship Behavior: A Survey Study in the Province of Erzurum, Turkey. Procedia Social and Behavioral Sciences, 99, 314-321.

Elstad, E., Christophersen, K. A. \& Turmo, A. (2011). Social Exchange Theory as an Explanation of Organizational Citizenship Behaviour Among Teachers. International Journal of Leadership in Education, 14(4), 405421.

Taşkıran, E. (2010). Liderlik Tarzının Örgütsel Sessizlik Üzerindeki Etkisinde Örgütsel Adaletin Rolü Ve Bir Araştırma. Doktora Tezi, Marmara Üniversitesi Sosyal Bilimler Enstitüsü İşletme Anabilim Dalı Yönetim ve Organizasyon Bilim Dalı.

Fatima, A. (2015). Impact of Organizational Silence on Organizational Citizenship Behavior: Moderating Role of Procedural Justice. Journal of Economics, Business and Management, 3(9).

Greenberg, J. \& Baron, R.A. (2000). Behavior in Organizations. 7th Edition, Prentice-Hall, New Jersey. 
He, P., Peng, Z., Zhao, H., \& Estay, C. (2017). How and When Compulsory Citizenship Behavior Leads to Employee Silence: A Moderated Mediation Model Based on Moral Disengagement and SupervisorSubordinate Guanxi Views. Journal of Business Ethics, 155(1), 259-274.

Henriksen, K. \& Dayton, E. (2006). Organizational Silence and Hidden Threats to Patient Safety. Health Services Research, 41(2), 1539-1554.

Kayış, A., 2009. Güvenirlik Analizi. Ş. Kalaycı (Ed), SPSS Uygulamalı Çok Değişkenli Istatistik Teknikleri. (403419). Ankara: Asil Yayıncılık

Khan N.U., Kaleem, M. \& Ullah, H. (2016). Relationship Between Organizational Silence And Citizenship Behavior - Mediating Role Of Commitments: Evidence From Khyber Pakhtunkhwa Universities, Pakistan Journal of Applied Economics: Special Issue 2016, 281-297

Kılıçlar, A. \& Harbalioğlu, M. (2014). Örgütsel Sessizlik ve Örgütsel Vatandaşlık Davranışı Arasındaki İlişki: Antalya'daki Beş Yıldızlı Otel İşletmeleri Üzerine Bir Araştırma Relationship between Organizational Silence and Organizational Citizenship Behavior: A Case Study on Five Stars Hotels in Antalya. ISARDER. 6. 328-346.

Kılınç, E. (2012). Hekim ve Hemşirelerde Örgütsel Vatandaşlık Davranışı, Örgütsel Sessizlik, Çalışan Performansı ve Aralarındaki İlişkinin İncelenmesi, Yüksek Lisans Tezi, Cumhuriyet Üniversitesi Sağlık Bilimleri Enstitüsü Sağlık Yönetimi Anabilim Dalı, Sivas.

Kılınç, E. and Ulusoy, H. (2014). "Investigation of Organizational Citizenship Behavior, Organizational Silence and Employee Performance at Physicians and Nurses, and The Relationship Among Them", Business Management Dynamics, 3(11):25-34.

Kleijnen, M., De Ruyter, K. \& Wetzels, M. (2007). An Assessment of Value Creation in Mobile Service Delivery and the Moderating Role of Time Consciousness. Journal of Retailing, 83, 33-46.

Love, A., \& Kim, S. (2019). Organizational Citizenship Behavior in Sport: A Perspective from Athletes. Journal of Sport Management, 33(1), 25-36.

Mehtap, Ö. (2011). Örgüt Içi Politik Davranışların Örgütsel Vatandaşlık Davranışı Üzerindeki Etkisi, Doktora Tezi, İstanbul: İstanbul Üniversitesi S.B.E.

Morrison, E. W. \& Milliken, F. J. (2000). Organizational Silence: A Barrier to Change and Development in a Pluralistic World. The Academy of Management Review, 25(4), 706.

Morrison, E. W. (2014). Employee Voice and Silence. Annual Review of Organizational Psychology and Organizational Behavior, 1(1), 173-197.

Nafei, W. A. (2016). Organizational Silence: Its Destroying Role of Organizational Citizenship Behavior. International Business Research, 9(5), 57.

Ones, D. S., Anderson, N., Viswesvaran, C. \& Sinangil, H. K. (2018). The Sage Handbook of Industrial, Work and Organizational Psychology: Personnel Psychology and Employee Performance. Los Angeles: SAGE.

Organ, D. W. (1988). Organizational Citizenship Behaviour: The Good Soldier Syndrome. Lexington, MA: Lexington Books.

Özdemir, L. \& Uğur, S.S. (2013). Çalışanların “Örgütsel Ses ve Sessizlik” Algılamalarının Demografik Nitelikler Açısından Değerlendirilmesi: Kamu ve Özel Sektörde Bir Araştırma, Atatürk Üniversitesi İktisadi ve İdari Bilimler Dergisi, 27(1), 257-281.

Pinder, C. C., \& Harlos, K. P. (2001). Employee Silence: Quiescence and Acquiescence as Responses to Perceived Injustice. Research in Personnel and Human Resources Management, 331-369.

Podsakoff, P. M., \& MacKenzie, S. B. (1989). A Second Generation Measure of Organizational Citizenship Behavior. Unpublished manuscript, Indiana University, Bloomington. 
Raju,V. \& Tamjis, R.B. (2019). The Relationship Between Organizational Citizenship Behaviour and Organizational Silence, International Journal of Engineering \& Technology, S. 8(1.10), 210-215

Riantoputra, C., Maharisa, W. \& Faridhal, T. (2016). Acquiescent and Defensive Silence in an Indonesian Context. Hubs-Asia. 20. 122. 10.7454/mssh.v20i2.481.

Şehitoğlu, Y. (2010). Örgütsel Sessizlik Örgütsel Vatandaşlık Davranışı ve Algıllanan Çalışan Performansı İlişkisi, Doktora Tezi, Gebze Yüksek Teknoloji Enstitüsü Sosyal Bilimler Enstitüsü, Kocaeli.

Tamuz, R.S. (2001) Engaging Organizational Voice: A Phenomenological Study of Employee's Lived Experiences of Silence in Work Group Settings. The Faculty of Graduate School of Education and Human Development of the George Washington University.

Turgut, M. ve Akbolat, M. (2017). Örgütsel Vatandaşlık Davranışı, Örgütsel Özdeşleşme ve Örgütsel Sessizlik İlişkisine Yönelik Sağlık Çalışanları Üzerine Bir Araştırma. Hacettepe Sağlık İdaresi Dergisi, 20. 357-384.

Van Dyne, L., Ang, S. \& Botero, I. (2003). Conceptualizing Employee Silence and Employee Voice as MultiDimensional Constructs. Journal of Management Studies, 40. 1359 - 1392.

Wan, H. L. (2018). Organisational Justice and Citizenship Behaviour in Malaysia. Puchong, Selangor D.E.: Springer Singapore.

Yeşilyurt, H. ve Koçak, N. (2014). İş Doyumu ve Örgütsel Vatandaşlık Davranışı Arasındaki İlişkinin Otel İşletmeleri Açısından İncelenmesi. Dokuz Eylül Üniversitesi Sosyal Bilimler Enstitüsü Dergisi, 16(2), 303 324.

Yücel, C. \& Samancı-Kalaycı, G. (2009). Örgütsel Güven ve Örgütsel Vatandaşlık Davranışı. Fırat Üniversitesi Sosyal Bilimler Dergisi, 19(1), 113-132. 